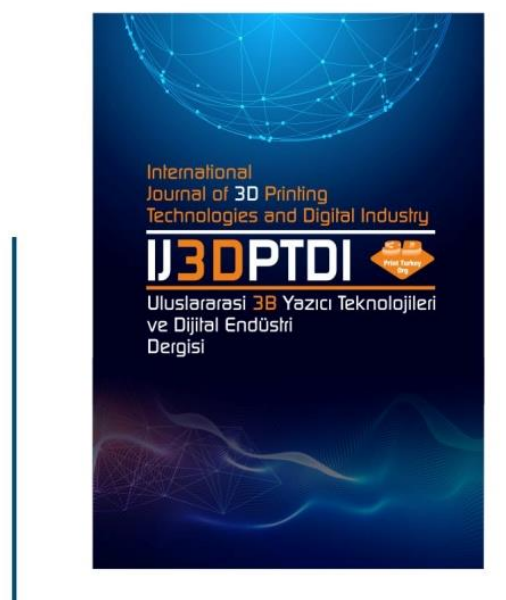

ULUSLARARASI 3B YAZICI TEKNOLOJILERI

VE DIJITAL ENDÜSTRI DERGISI

INTERNATIONAL JQURNAL QF 30 PRINTING TECHNOLOGIES AND DIGITAL INDUSTRY

ISSN:2602-3350 [Online]

URL: https://dergipark.org.tr/ij3dptdi

\title{
OUTER SHELL FLEXIBILITY IN KINETIC ARCHITECTURAL DESIGN AND UTILIZATION OF INTEGRATED SYSTEMS
}

Yazarlar (Authors): Nurgul Inan ${ }^{\text {(D) }}$, Mehmet Tayfun Yildirim (iD

Bu makaleye şu şekilde atıfta bulunabilirsiniz (To cite to this article): Inan N., Yildirim M.T. "Outer Shell Flexibility In Kinetic Architectural Design And Utilization Of Integrated Systems” Int. J. of 3D Printing Tech. Dig. Ind., 5(3): 400-415, (2021). 


\title{
OUTER SHELL FLEXIBILITY IN KINETIC ARCHITECTURAL DESIGN AND UTILIZATION OF INTEGRATED SYSTEMS
}

\author{
Nurgul Inan ${ }^{a}(\mathbb{D})^{*}$, Mehmet Tayfun Yildirim ${ }^{\mathrm{b}}$ (i) \\ ${ }^{a}$ OSTIM Technical University, Faculty of Architecture and Design, Department of Industrial Design, Ankara \\ ${ }^{\mathrm{b}}$ Gazi University, Faculty of Architecture, Department of Architecture, Ankara \\ *Corresponding Author:nurgul.inan@ostimteknik.edu.tr
}

(Received: 26.08.2021; Revised: 29.09.2021; Accepted: 18.10.2021)

\begin{abstract}
Today, developing technology and globalization change the cultures, lifestyles, and needs of societies. This change also impacts the expectations from architectural spaces. Spaces designed to perform a predetermined function may be insufficient to meet the changing needs over time. The aim of this study is to show the flexibility that the movable structural elements bring to the space. In this context, we propose integrating movable inner and outer shell structural elements to achieve specific functionality and meet the various functional capacity needs. In this study, a sample design was visualized to demonstrate the use of integrated kinetic building elements and was discussed its applicability with existing technologies and the advantages that it can provide. As a result, it was observed that kinetic building elements practically provide spatial flexibility and functional diversity in architectural design. In addition, the visuals show that the system is practical, applicable and efficient. Kinetic and flexible space design can be evaluated in "Generative and Parametric design" by means of to obtain variable solutions and functional sustainability according to different functional expectations from design.
\end{abstract}

Keywords: Kinetic Architecture. Functional Sustainability. Architectural Mobility. Outer Shell Flexibility. Integrated Systems.

\section{INTRODUCTION}

Architecture is the art of building to provide the various vital needs of people. However, there may be changes in the users, needs, functions, environmental conditions, or tools used during the life of buildings. Stable spaces designed to provide a specific function may become insufficient due to these changes. In such cases, the transformability and interchangeability features of the moving building elements are considered as a solution by the designers due to the flexibility they create. Today, this understanding in which movable building elements are used effectively is defined as kinetic architecture. Although movement in architecture has been used for many years, there is limited variety of practices on flexible buildings. The aim of this study is to offer utilization of integrated inner and outer shell structural elements for creating flexible spaces to meet the changing needs.

In the second part of the study, the concept of kinetic architecture and the purposes of using kinetic systems are mentioned. In the third part, a typological classification of kinetic systems is made according to the movements they use. Then, a system that includes multiple building elements with different movement types is proposed. In systems where the movement of two or more structural elements is required, any component force another part connected to it into movement. Movement types can be sliding, pulling, pushing or rotating by rods, rotaries and wheels. These systems, called integrated systems, can move horizontally or vertically and provide aimed position [1]. In this study, there is an outer shell that can be added to the building from the outside. The outer and inner shell building elements work integrated. So, it provides an easy, practical and inexpensive solution to different spatial requirements. A sample design was visualized by a computer program to show how this system works. $3 \mathrm{dmax}$ and Autocad programs were used for visualization and simulation. This simulation shows the variety of space and capacity created by moving building elements. Due to computer visualization, it was calculated the area gains provided by the movements of the structural elements before constructing 
the building. At the same time, movements of components were animated to see the aplicability of the system. In this way, we believe the buildings will be used more flexible for a longer period of time.

\section{KINETIC ARCHITECTURE}

According to Bayazit [2], an environment or an architectural space is the result of three important ideas:

- The purpose of designing the building or space,

- Available facilities to construct the building or space,

- The emotional effects of the space on people and its response to functional needs.

Until recently, many architects accepted that the most important design criteria were providing predetermined functions, resistance to external conditions, and permanence. It is clear that stable spaces cannot meet today's constantly changing needs [3]. So architects have begun to design dynamic, transformable, interactive buildings with moving building elements that can adapt to the environment and needs. This type of architectural understanding is known as kinetic architecture.

The usage purposes of the movement in architecture can be grouped under the following headings.

- Needs for Flexibility

- Control of physical environment

- Inspired from nature

- Energy production

- Earthquake control

- Visual change-aesthetic purpose

- Information-interaction purpose

Today, with the help of developing technology and new materials, the usage of movement in buildings is increasingly common. The movement, which constitutes the essence of kinetic architecture, is explained in the dictionary of the Turkish Language Association as "the change of the state and place of an object, motion, action" [4]. The concept of movement in architecture can be expressed as the ability to change the current state, form, or position of the entire building, part of it, or just some building elements.

In some architectural designs, the movement of most of the building elements or even the whole building is involved. In the mid-20th century, the Archigram group designed the Walking City Project in Figure 1. In this project, not only one building but also building communities were moving. Thus, the limits of the concept of movement have been pushed [5]. However, large building movements are not yet seen in cities as in these utopias.
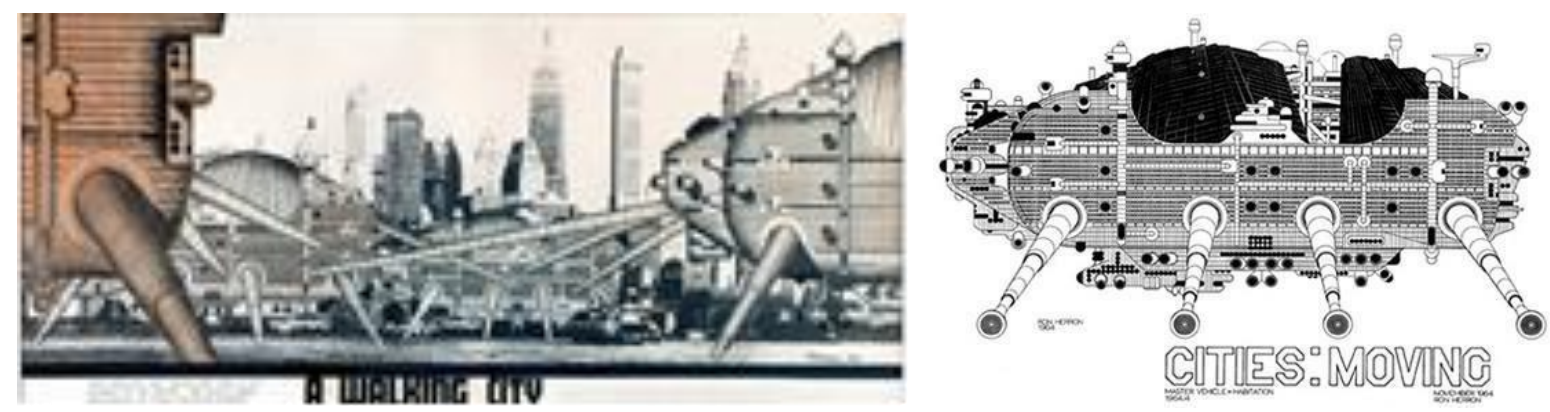

Figure 1. Walking City Project [6].

\section{TYPOLOGICAL CLASSIFICATION OF KINETIC SYSTEMS}

In order to adapt to today's constantly changing conditions, the demand for flexible, adaptable, changeable, and convertible architectural products is increasing. Developing technology and lightweight construction materials help to increase examples and types of smart and mobile buildings which are compatible with their surroundings and can better respond to needs. Kinetic systems can be classified according to the type of motion, the material used, or the purpose of the motion. According to Korkmaz, 
kinetic systems are divided into two basic systems: mobile and convertible [7]. While mobile systems can change location, convertible systems can change their form. In this study, convertible systems will be emphasized.

\subsection{Mobile Systems}

In these systems, the building is not designed for a specific region. After the utilization phase, the completed building is moved to another place for reuse (Figure 2). The mobile systems can be grouped under three headings according to the construction technique and the way of transportation.

- Complete portable systems

- Repositionable systems

- Detachable systems
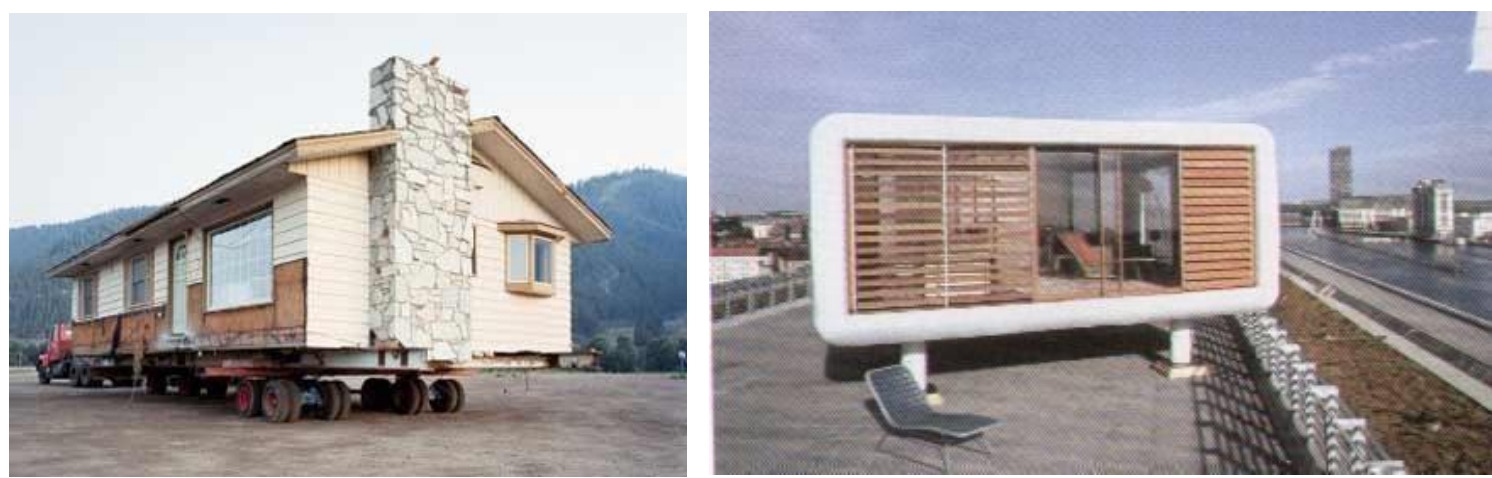

Figure 2. Mobile systems [8]

\subsection{Convertible Systems}

In kinetic architecture, structures that can change their location are generally disassembled and rebuilt in their place or elsewhere while maintaining their original form. On the other hand, in the convertible structures, some changes occur in the internal or external form without changing the current position. In these systems, sometimes only a specific part can move, sometimes other elements can follow this movement. The whole system can become dynamic owing to this integrated operation of the building elements. In such structures, it is possible to change the shape either by using the deformability properties of the flexible material or with the help of various movements of the rigid elements.

In kinetic structures, rigid elements can move by folding, sliding, expanding and contracting, or rotating. However, some structures have more than one motion mechanism and can be included in different classifications (mixed systems).Folding is a form of transformation in which there is no deformation in the structural elements, but the general form transforms via the changes in the position or direction of the building elements. Folding systems are folded at specific points in order to provide ease of transportation or to reduce the volume during storage. Therefore, they are suitable for mobile structures. Folding systems are frequently used in industrial products and architecture. Transformation of Planar and 3D forms is required knowledge of "Topology of Geometry". Term of topology means relations of surfaces, edges (segments) and nodes (corners, bar intersctions). This information gives turning possibilites of faces, places of pivot edges or rotating bolt places on corners (Figure 3).
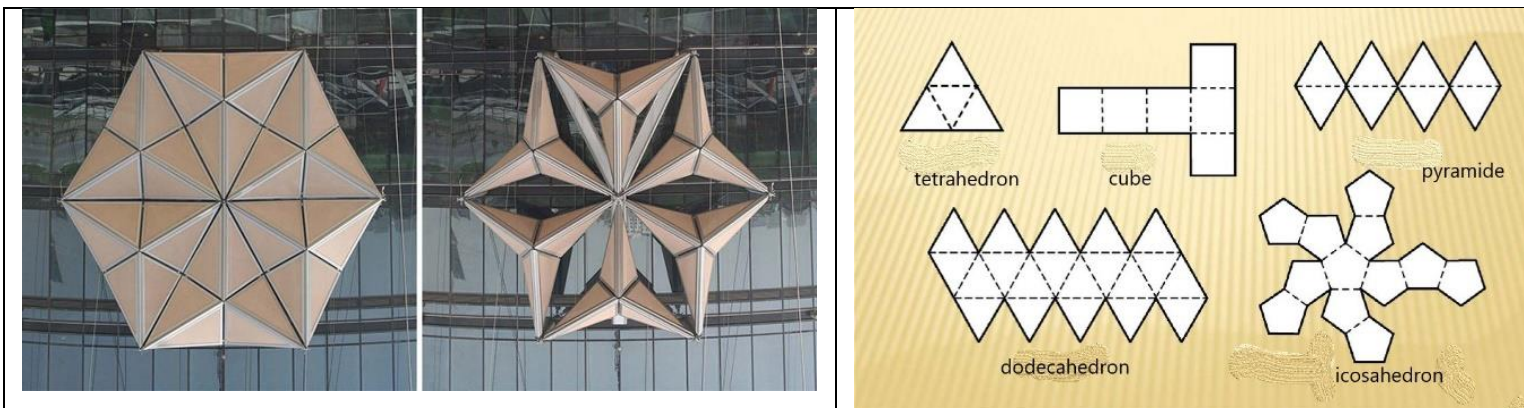

Figure 3. Topological relations of edges and corners for surface movements 
The Pfalzkeller Emergency Service building in Switzerland is an interesting example of folding systems. In order to preserve the historical character of the building, which was included in the list of world heritage list by UNESCO, there is a glass roof above the additional structure, which was taken underground. On the top of this glass roof designed by Calatrava, there is a folding construction to control daylight and temperature (Figure 4) [9].
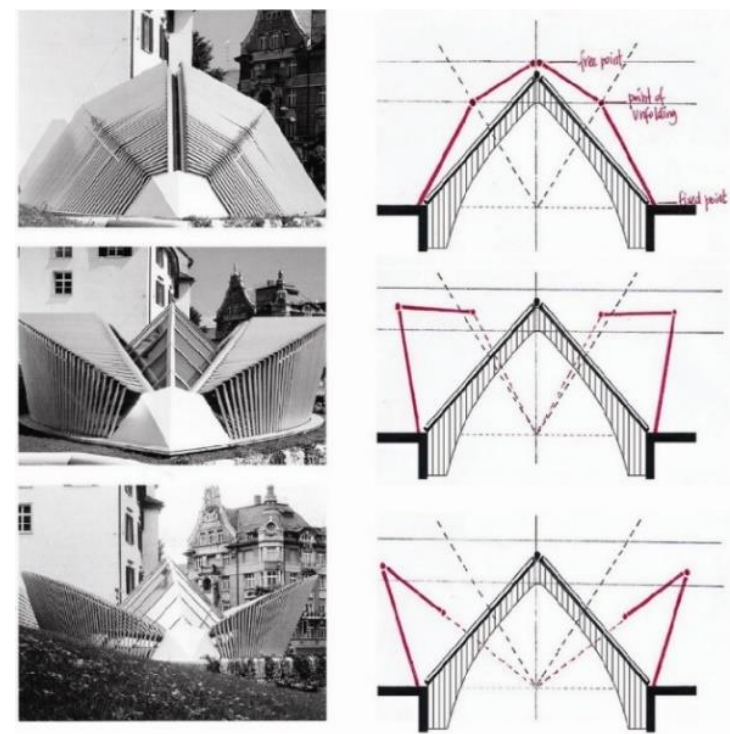

Figure 4. Construction of Pfalzkeller emergency service center roof construction [9].

In expanding-contracting systems, the structural elements move from the points where they are connected to each other, and the volume expands by opening. When the system is expanded, the building elements can carry their own load. They are easily manufactured, portable, installable, removable, and reusable systems [10]. These systems, which are mostly used in the toy industry, have been developed by Hoberman, and inspired architecture (Figure 5).

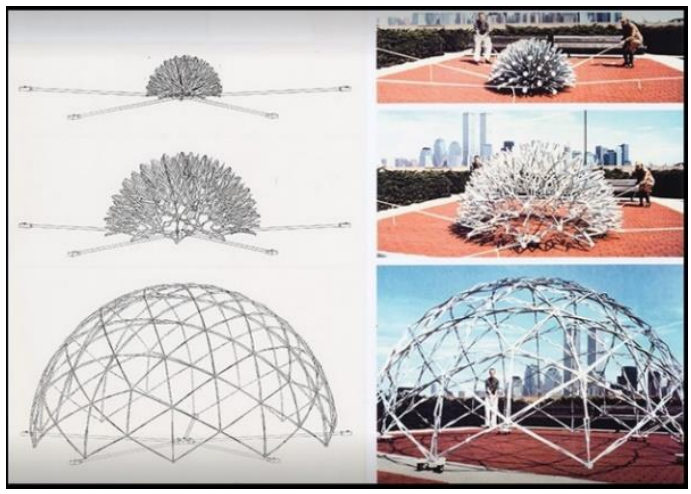

Figure 5. Space created inspired by the Hoberman sphere [11].

In rotating systems, structural elements are connected to each other by a mechanism that rotates around a center [12]. One of the best examples of rotating structures is the Dynamic Tower in Dubai, designed by David Fisher (Figure 6). Dr. Fisher describes his rotating tower as "designed by life, shaped by the time" [13]. 


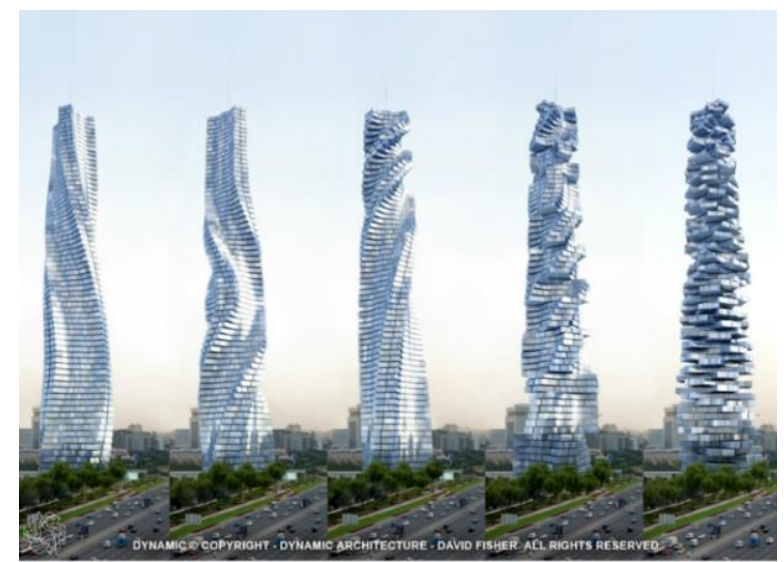

Figure 6. Changing views of the Dynamic tower [13].

In sliding systems, all or some of the system slides and displaces due to its special mechanism. The sliding action can be occur by intertwining or rotating mechanisms made of a wheel-like vehicle placed on a rail [14]. In architecture, sliding systems are also used for different scales and purposes, such as opening doors, windows, roofs, and movement of dividers or outer walls. Sliding House is an impressive structure built with a sliding structure. It was designed by Alex De Rijke, and was built in SuffolkEngland in 2009 (Figure 7). The 50 tons outer shell of the house is located on rails, and when it slides, a greenhouse comes out [15].
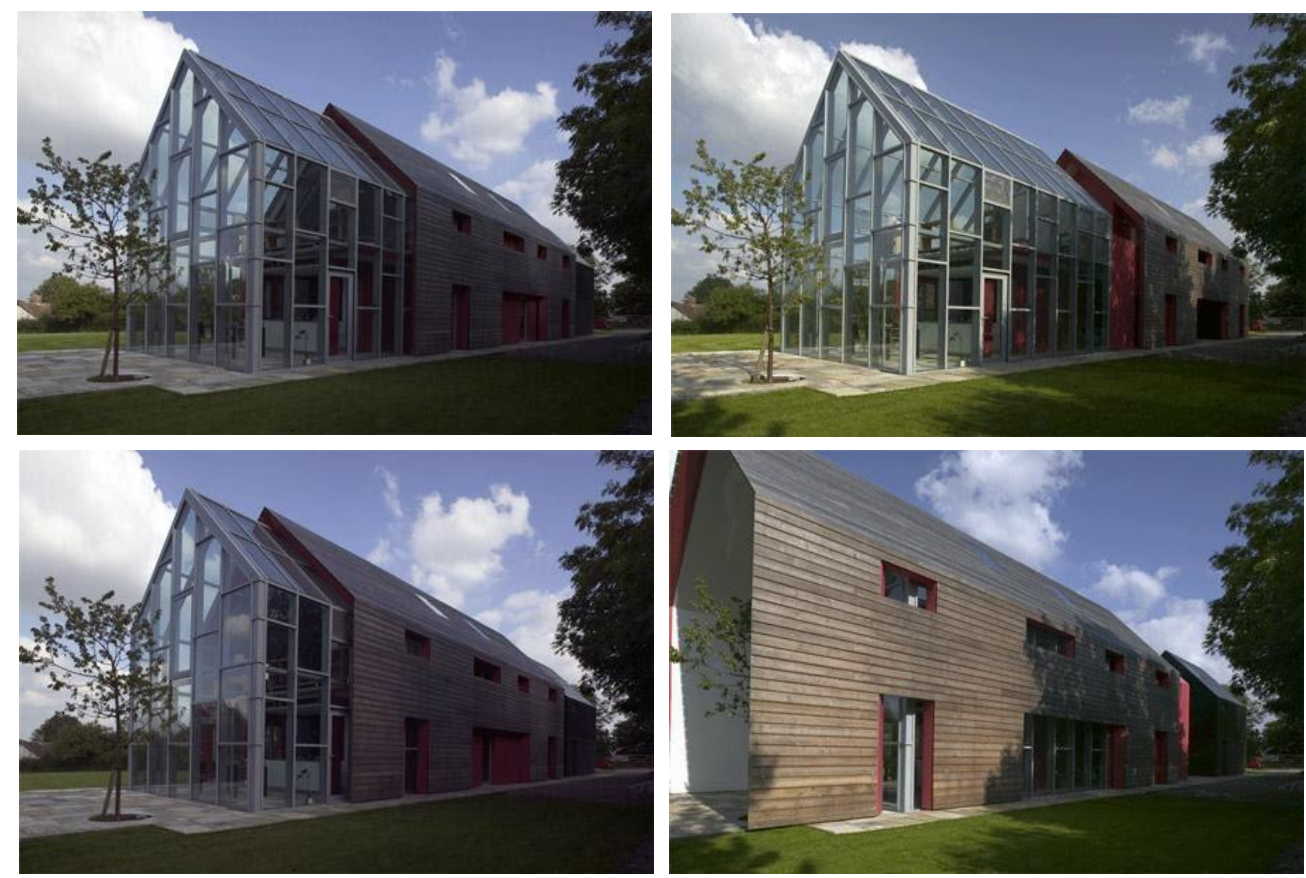

Figure 7. Sliding House [15].

In convertible soft-form structures, it is possible that the system can partially or completely change its shape, expand and contract depending on the elasticity of the material used. The form of the building can be symmetrical or amorphous. Today, advancements in nanotechnology enable the study of numerous smart materials. According to Altun [16],

"There are various predictions that, in the future, depending on the commands given by the computer, building texture can change such as the material can change between solid, liquid and gas phases, sometimes it can be opaque and solid, sometimes transparent and fluid." 
A mechatronic system consists of a combination of machinery, electronics, software, and control disciplines. Today, "smart buildings", which are the result of the use of mechatronic systems in architectural products, have the feature of receiving and analyzing data from their environment, and responding to it [17]. An example of such systems is Bill Gates's Microsoft house (Figure 8). In this house, which is defined as the house of the future, everything can meet the needs of the user with the support of computer programs and various electronic equipment. While the interior walls of the house look like an ordinary wall, they change into large screens. It can be said that these screen-walls, which are defined as windows opening to technology, create an intersection between the virtual and real worlds [18].

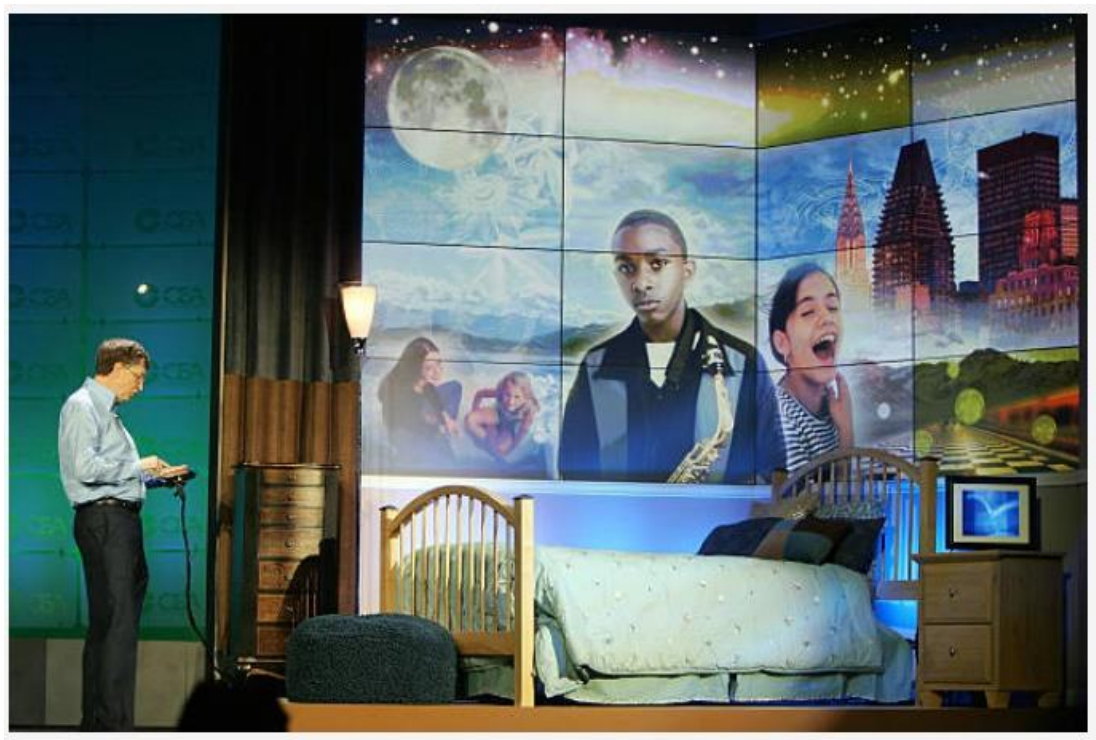

Figure 8. A view of the Microsoft house [18].

Kinetic architecture applications can be made manually or automatically in smart buildings by using sensors. Physical, atmospheric and visual changes can be observed by sensors in smart buildings. Sensors, special control chips, control systems under the control of computers (mecatronic facilities) and network connections can be further design data by means of kinetic architecture. [19]. According to Andrä and Fink, today kinetic architecture is more and more converging towards mechatronic design, due to the integration of electronics and computer technology into architectural design [20]. The Reichstag Dome in Berlin by Foster + Partners is a good sample of a mechatronic system. In this building, a large sun shield moves electronically according to the movement of the sun and blocks the sun's rays that can disturb the people inside (Figure 9).

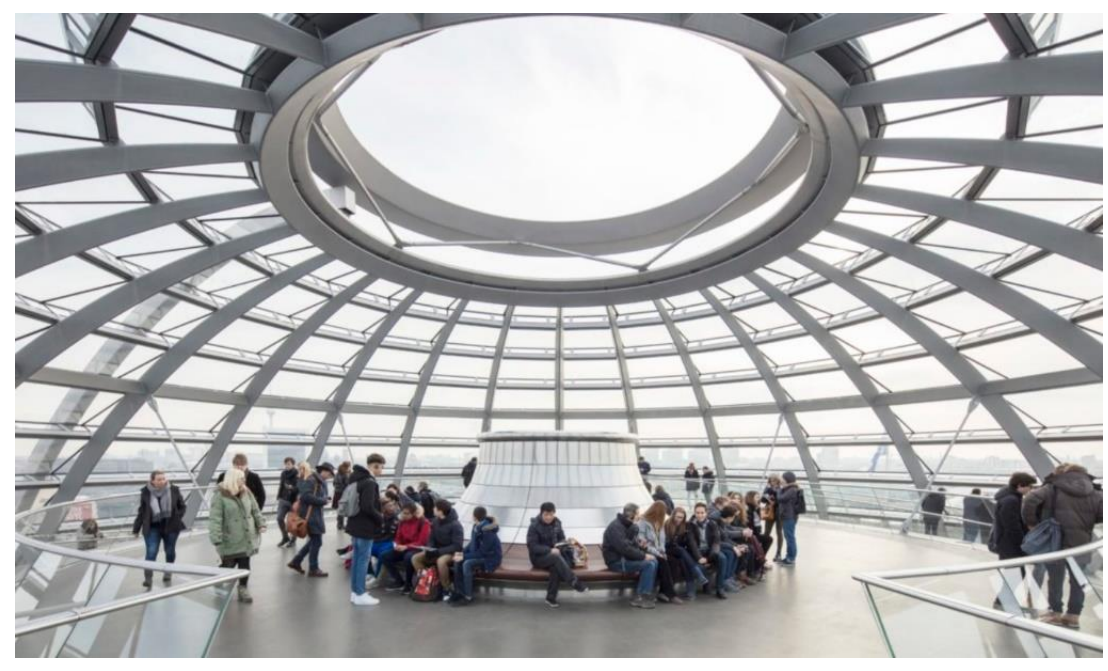

Figure 9. Reichstag Dome, steel and glass structures by Waagner-Biro [21]. 


\section{MOVABLE OUTER SHELL IN KINETIC ARCHITECTURE}

In buildings, the outer shell is the building elements that limit the interior spaces, protect them from climatic conditions, noise, bad smell, unwanted solar rays, and form the facades of the buildings [22]. For many years in architecture, the outer shell was stable. As technology advanced, architects began to design movable facades that responded to changing conditions. These types of facades generally try to establish a relationship between aesthetics and function. One of the examples $\mathrm{c} n$ be given for this type of relationship is the Al Bahar Towers building built by Aedas Architecture in Abu Dhabi (Figure 10).
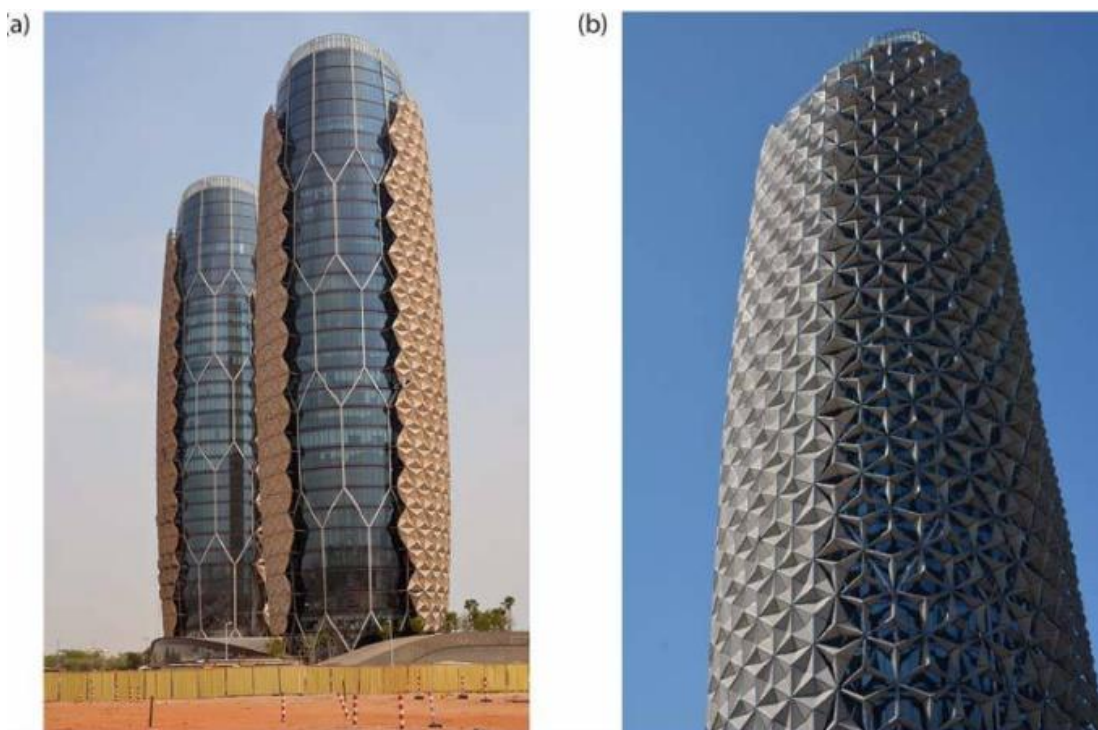

Figure 10. (a) Northern facade and (b) south facade of Al Bahr Towers, with some opened and closed shadingdevices [23]

The umbrella-like panels on the facade open and close according to the movement of the sun. Thus they protect the inside of the building from heat and brilliant light, reduce the need for air conditioning and make the building more sustainable. The star-shaped outer shell design is not only aesthetic, but also respects cultural heritage as it is inspired by traditional Islamic systems. The shading device system contains stainless steel supporting frames, aluminum dynamic frames, and fiberglass mesh infill (Figure 11). To check the coordination between the various building components, a digital model was used to guarantee the integration between the fiberglass mesh, the structural steel frame and the concrete core [24].
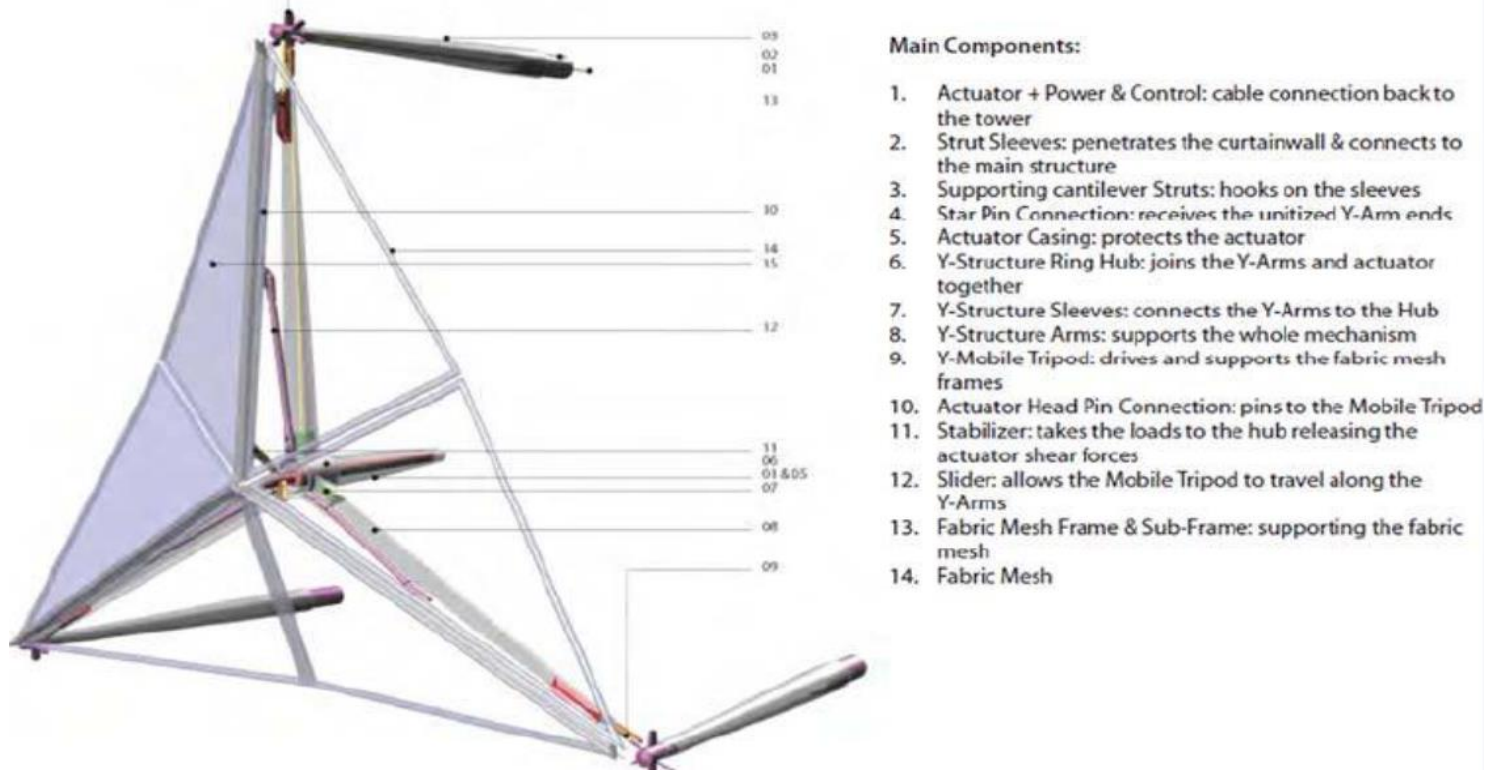

Figure 11. Detailed 3D model of an individual shading device [25] 
Although kinetic facades are new phenomenon, their uses and forms are already very diverse. From triangular modules to huge awnings, from aluminum sheets to surface-projected animations, each design serves a unique purpose and takes on a unique form. Movable outer shells not only respond to environmental problems, but also expand or shrink to provide functional flexibility in interior spaces. With the increasing variety of applications, kinetic facades can be a very powerful tool to bring new and technological solutions to flexibility, sustainability and aesthetics.

\section{PROPOSAL FOR OUTER SHELL AND INNER FUNCTION INTEGRATION IN ARCHITECTURE}

Today, rapid changes due to time make it necessary for buildings to adapt quickly to this change. Achieving this rapid change and adaptation depends on the flexibility capacity of the structure. Flexibility is a design approach that includes spatial and structural strategies that enable the building to meet the changes in the face of possible changes in the process. According to İslamoğlu et. al [26] flexibility is an important design criterion in architectural design. At the core of this concept is a timerelated power that provides sustainability, freedom and user participation, social, cultural and economic benefits. Achieving this power depends on design decisions and flexibility strategies.

Famous architects have different approaches and practices regarding flexible design. Norberg Schulz [27] emphasizes that flexibility can be achieved in two ways. The first is the expansion or contraction of the building by adding or removing elements without losing its integrity. The second is that elements and their relations can be changed. Movable structural elements can change space divisions or the environment of spaces. In a design process for kinetic architecture, there are many complex requirements. Kinetic architecture not only deals with movable parts added to static architecture, it also need to viewing a building in a process of change. Ferschin and his friends [24] propose a design process for kinetic architecture that consists of three major stages (Figure 12).

"A suitable rapid prototyping environment for kinetic architecture has to adequately support the design process by providing for modelling, visualization, simulation, control, and evaluation of the virtual and physical prototypes throughout the entire design process. This implies above all, an iterative design process with repeated evaluation of suitability and aesthetic qualities." [28]

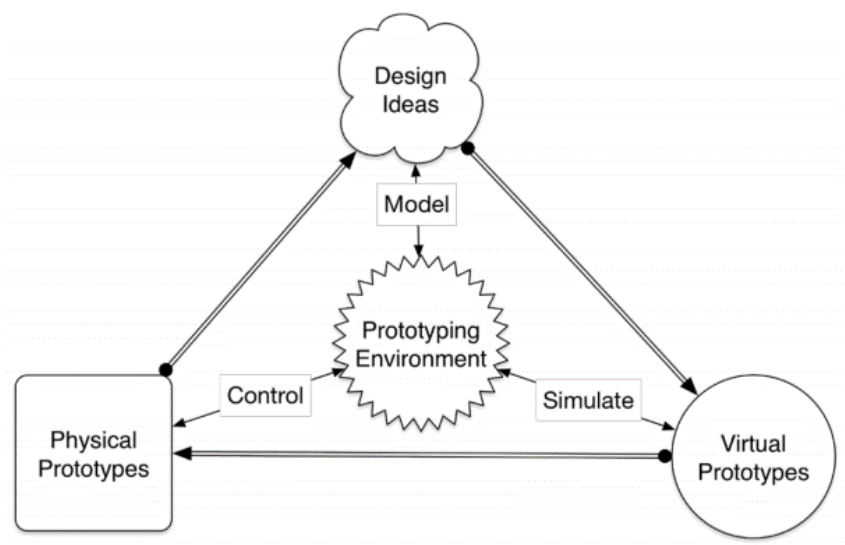

Figure 12. Design process for kinetic architecture [28]

Although the number of kinetic architecture applications is increasing today, it can be said that it is still in its infancy since it is costly and requires interdisciplinary expertise. Some of the large and complex works in the world are still at the project stage. When the current examples both in our country and abroad are examined, it can be seen that there are still some lacks. Architectural spaces may need small or large areas depending on the changes in their usage and capacity. This study proposes the use of moving building elements to meet these constantly changing needs in places in an easier, economical and practical way.

To set an example for such uses of moving elements, a new and original design is created for audienceoriented spaces such as sports halls and auditoriums. In the design, the outer shell and inner shell 
building elements work integratedly. The ability of this proposed design to be implemented to existing buildings is also considered an important feature. Although the design is a small part of a building, it can be an example for designers as a solution for flexible buildings. The main building elements of the proposed design are the folding walls, the moving roof, and the telescopic tribunes that work together. When the walls moving on wheels are unfolded, the space expands outward or when they are folded, the space becomes smaller (Figure 13).

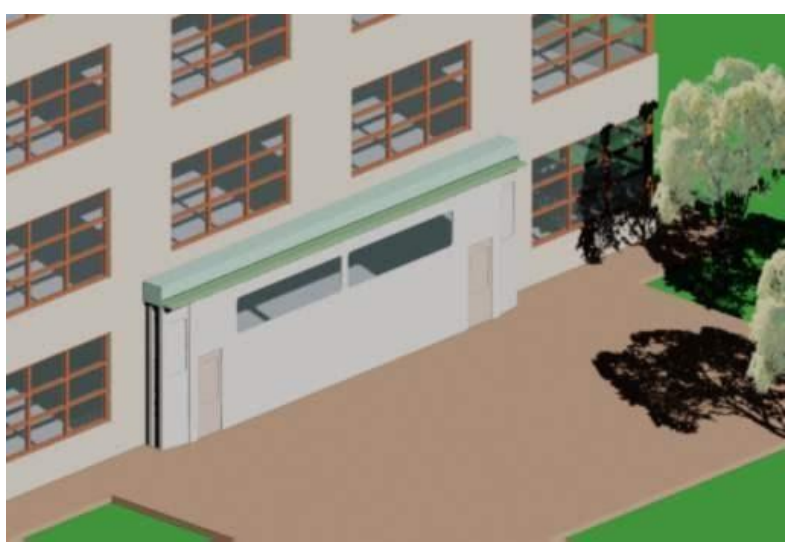

(a)

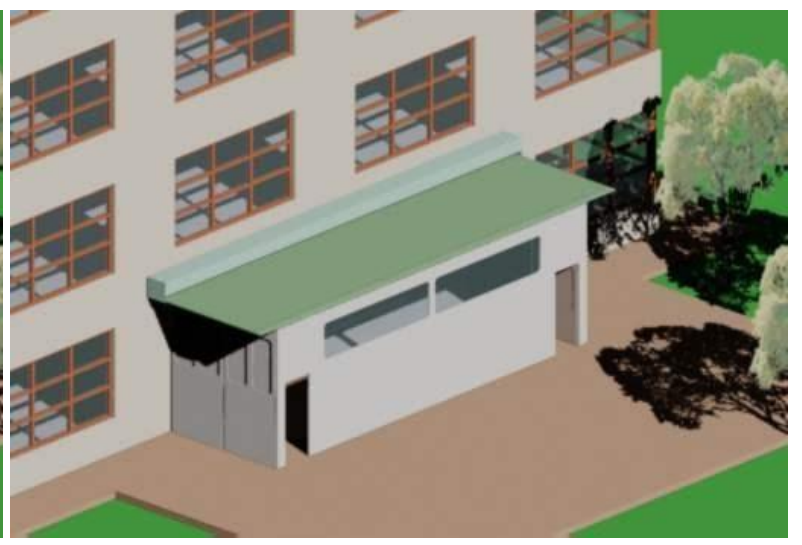

(b)

Figure 13. Folded and unfolded positions of the walls.

In this kinetic wall system; gear (for power transmission in the back and forth movement of the system), scissor (to keep the carrier system in balance), sliding (for the back and forth movement of the system), folding (on the side panels), intertwining (for collecting and opening the tribunes) and rotating (on roof cover) systems work together. Hence it is a hybrid system. In Figure 14, the powertrains, carrier elements, side panels, and their movements are shown.

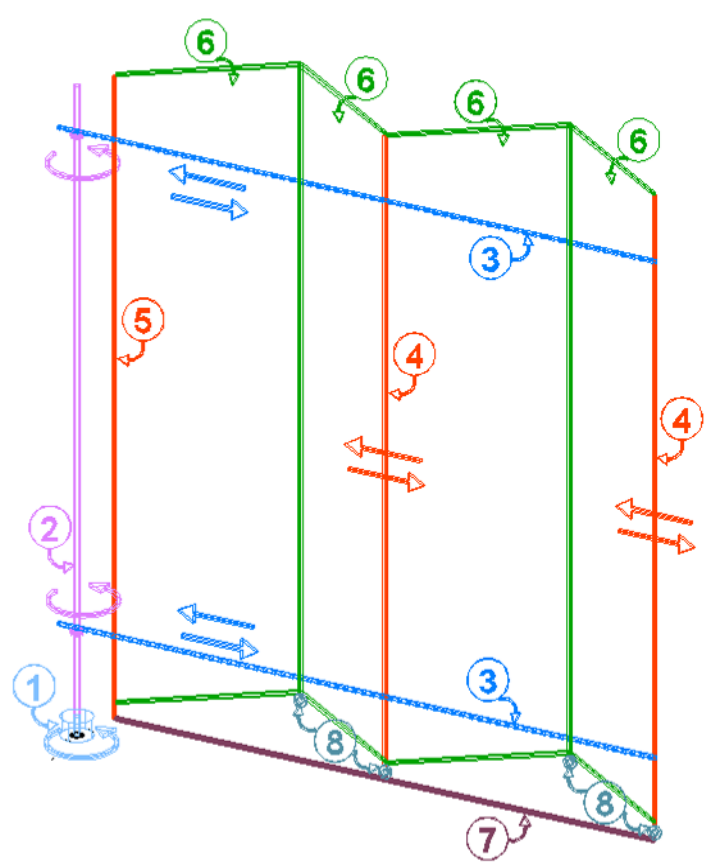

1. Engine

2. Vertical gear shaft

3. Horizontal rack gear (worm gear)

4. Carrier moving steel column

5. Fixed carrier steel column

6. Side panels

7. Rail

8. Wheel

Figure 14. Motion of the architectural and mechanical elements used in the walls

The rotating vertical gear shaft by the power of the engine drives the rack gear forward or backward in the horizontal direction. The movement of the rack gear towards the outside of the building allows the walls to expand outwards. The motion flow diagram of the building elements working together is shown in Figure 15. Virtual prototype tests all movements of parts in the system where forces are transferred 
to each other. However, functional aspects need to be simplified to provide rapid feedback during the design process. If there are new parts, they can be available by 3D printing or $\mathrm{CNC}$ milling.

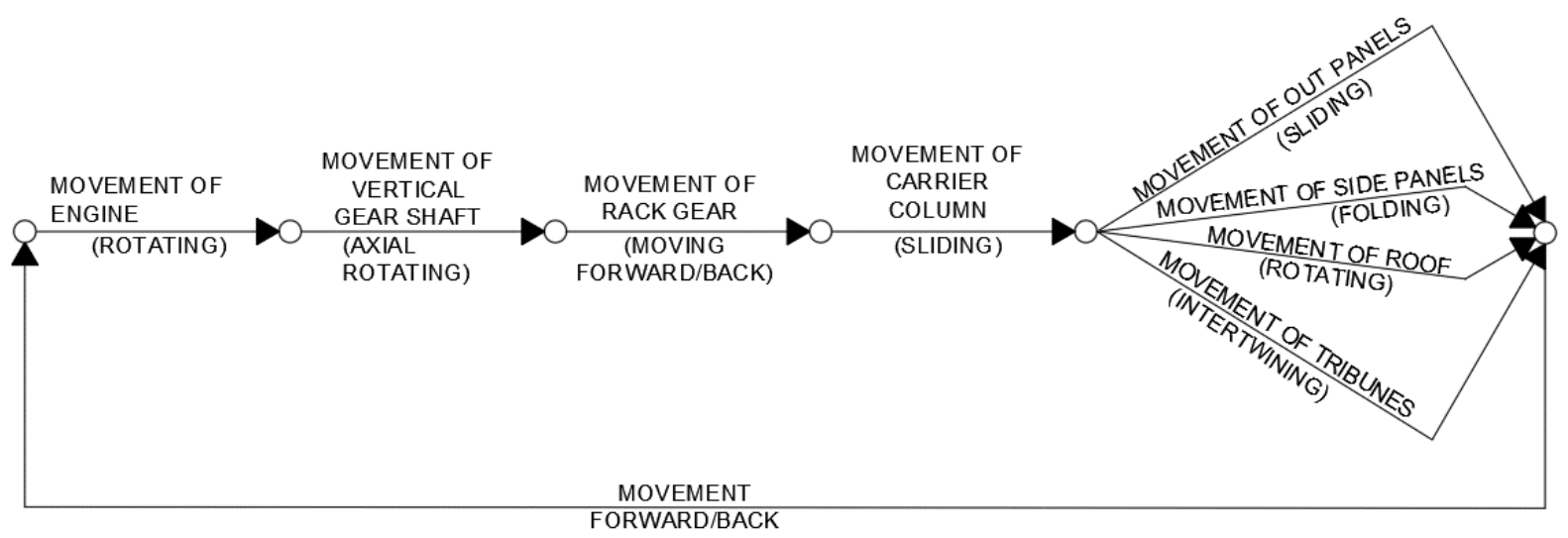

Figure 15. Motion flow diagram.

The movement of the walls affect the roof and they open and close synchronously. Although there are various alternatives for roofing, in this design, a system in which the membrane roof is collected in a box is used (Figure 13). The roof cover is opened or hidden by wrapping around the mechanism inside the box. In such a roof system, the box is placed inside or outside the outer wall of the building. However, the roof may have different movements depending on the covering material or the features of the building. As shown in Figure 16, if the existing building is suitable, the roof can move linearly into the building.

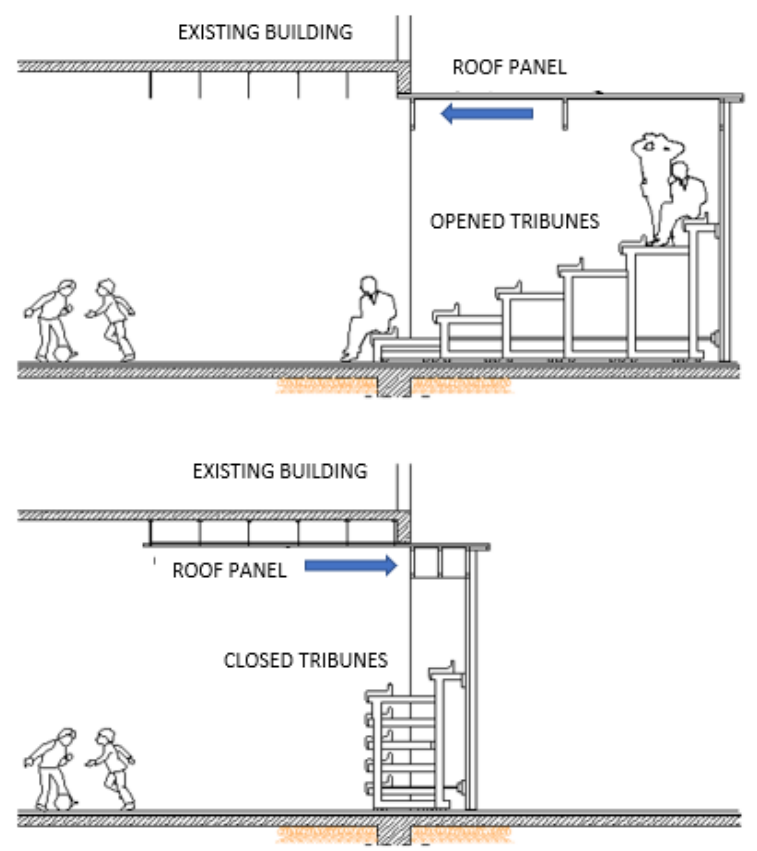

Figure 16. The roof moving linearly into the building.

In this proposed design, the other important element that constitute the mobile system is the telescopic tribunes. If there is no audience, telescopic tribunes can intertwine and provide a large space. When the mobile tribunes are open, the audience can sit. The tribunes can move synchronously with the movement of the wall or independently. While the tribunes are opened, the walls expand outwards to prevent the space from narrowing (Figure 17). In a smart building, sensors detect the number of users entering the door and the computer calculates this information and opens only the required quantity of stands. 


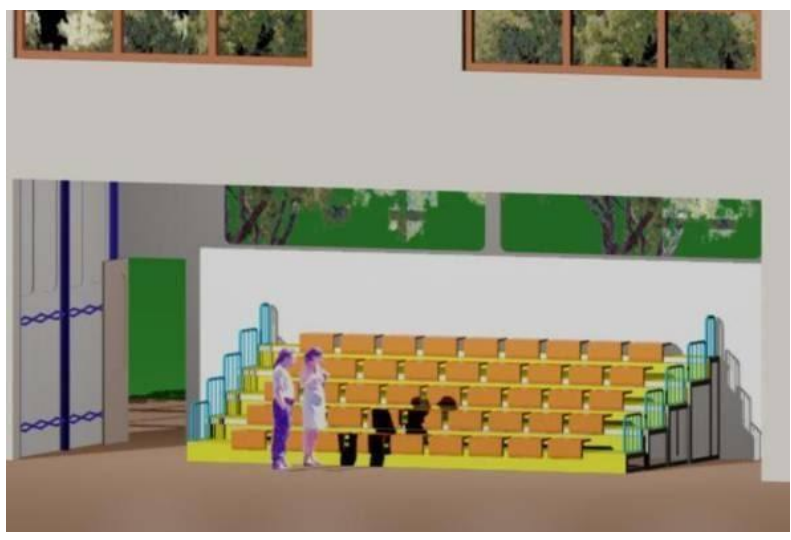

(a)

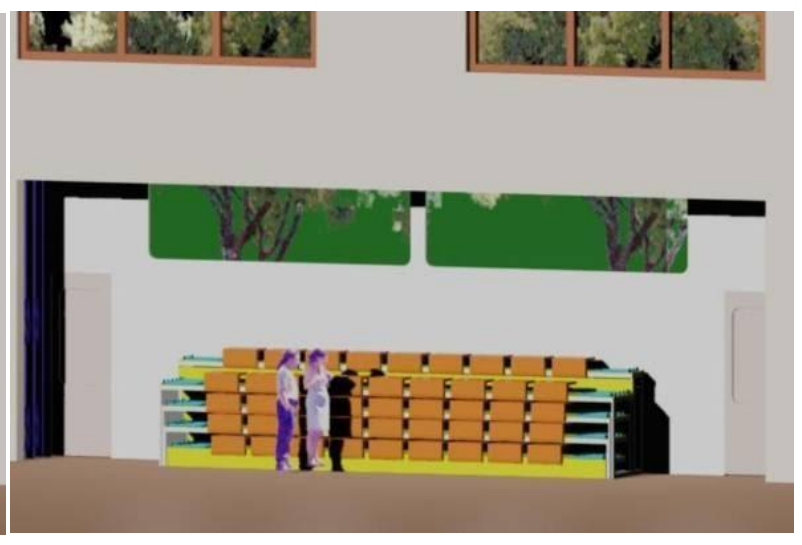

(b)

Figure 17. Opened and closed tribunes.

In this study, in order to evaluate the advantages provided by the design, the telescopic tribunes with folding wall system was compared to the stable tribunes with fixed wall system. Both telescopic and stable tribunes were considered to have 3,6 and 8 rows. Telescopic tribunes with 3,6 and 8 rows are shown in Figure 18. The plan sizes and interior height measure of the space may limit the numbers of the rows of tribunes.

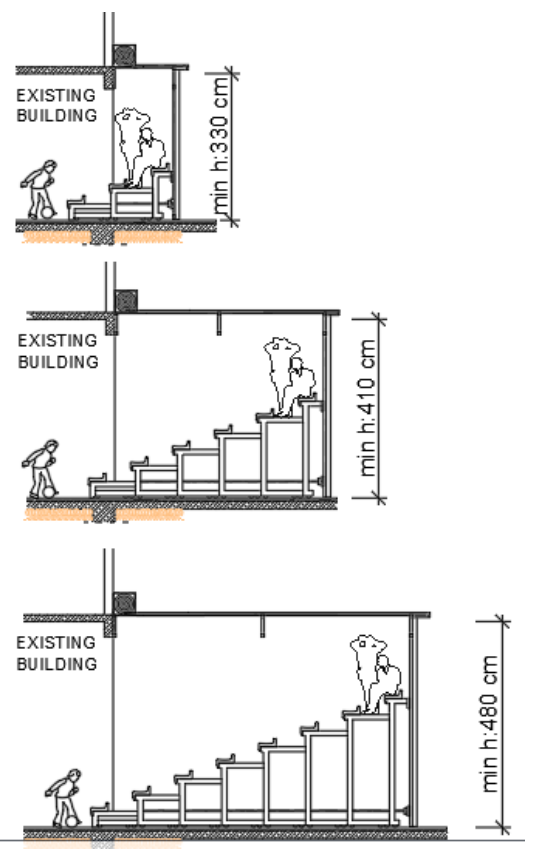

Figure 18. View of telescopic tribunes with 3, 6 and 8 rows.

In this study the minimum required height measurement for a person standing on the back row of the tribunes was assumed as $225 \mathrm{~cm}$. The minimum height measurement of the space was calculated by adding $225 \mathrm{~cm}$ to the height of back row. Required minimum heights according to the different number of rows are shown in Table 1.

Table 1. Required minimum heights according to the number of rows.

\begin{tabular}{|c|c|}
\hline Number of Rows & Min Height \\
\hline 3 & $330 \mathrm{~cm}$ \\
\hline 6 & $410 \mathrm{~cm}$ \\
\hline 9 & $480 \mathrm{~cm}$ \\
\hline
\end{tabular}


In the study, two different widths, 8 meters and 16 meters, were chosen as the width of the space for comparison. If the width of the space is less than 8 meters, as the number of seats will decrease it will not be economic. If the width of the space is more than 16 meters, the profile dimensions and scissors height of the carrier system will increase. As a result, the carrier system gets heavy and movement becomes more difficult. In practice, the width of the space varies according to the axle spacing of the existing building, the needs, the condition of the land and the zoning regulations.

As shown in Figure 19, we divided the telescopic tribunes into six types (A, B, C, D, E, F) consisting of 3,6 and 8 rows for 8 and 16 meters of widths.

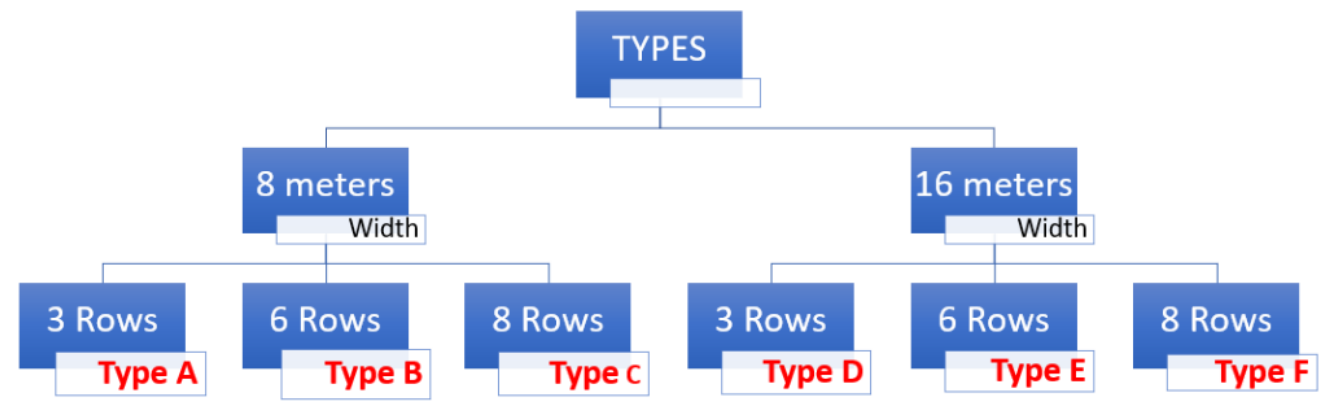

Figure 19. The properties of different types of the tribunes.

The plan drawing in figure 15 shows the different movements of the tribunes and walls for type $\mathrm{B}$. In this design, if the tribunes and the folding walls are opened at the same time, there is no loss of space inside (Figure 20b). When the tribunes are closed and folding walls are opened to expand to the outside, it creates more interior space (Figure 20c).

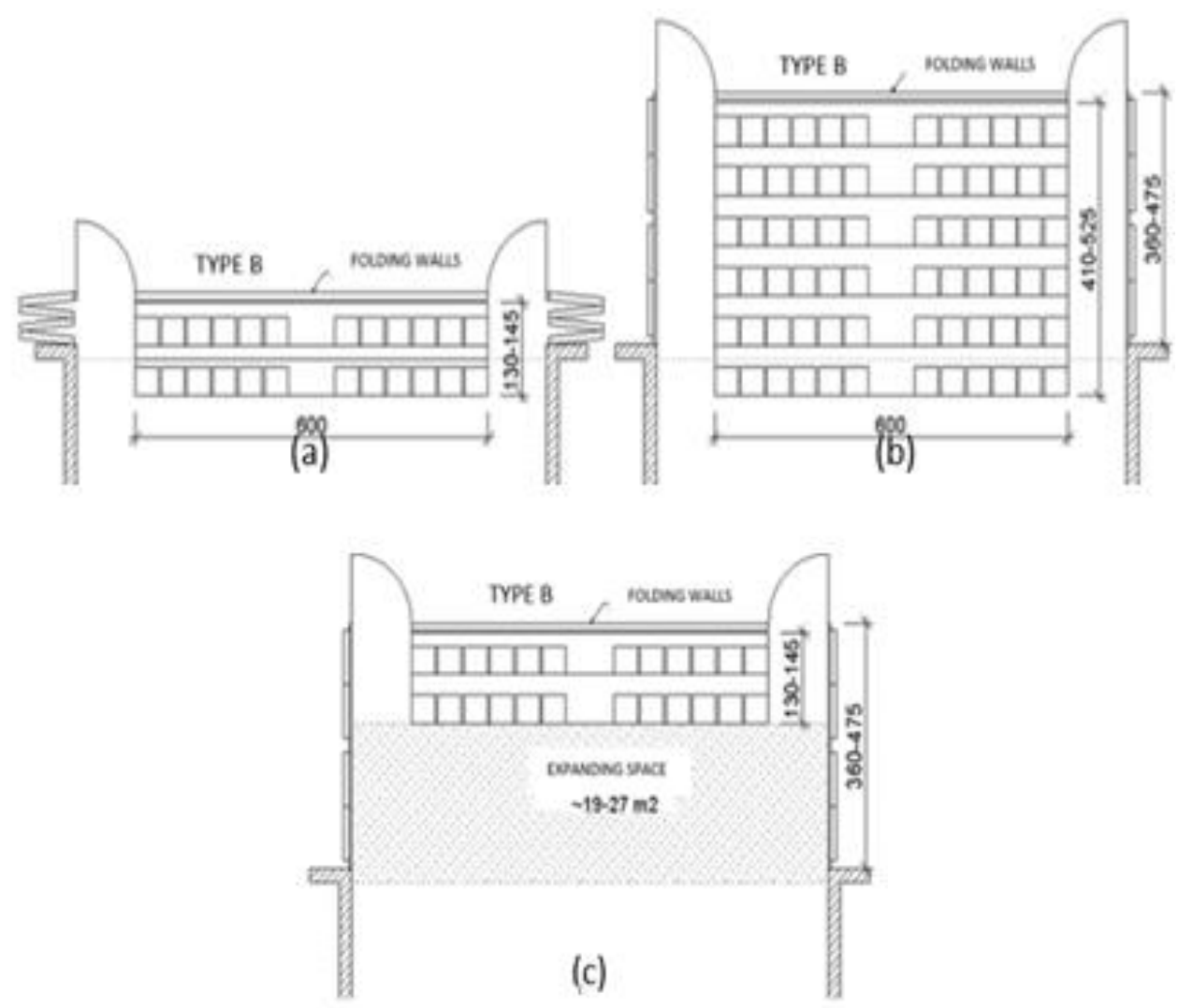

Figure 20. The different movements of the tribunes and walls for type B. 
In Figure 21, in order to calculate how much space will be gained for each type, depth measurements of 3, 6 and 8 rows of telescopic tribunes in their opened and closed positions are shown.

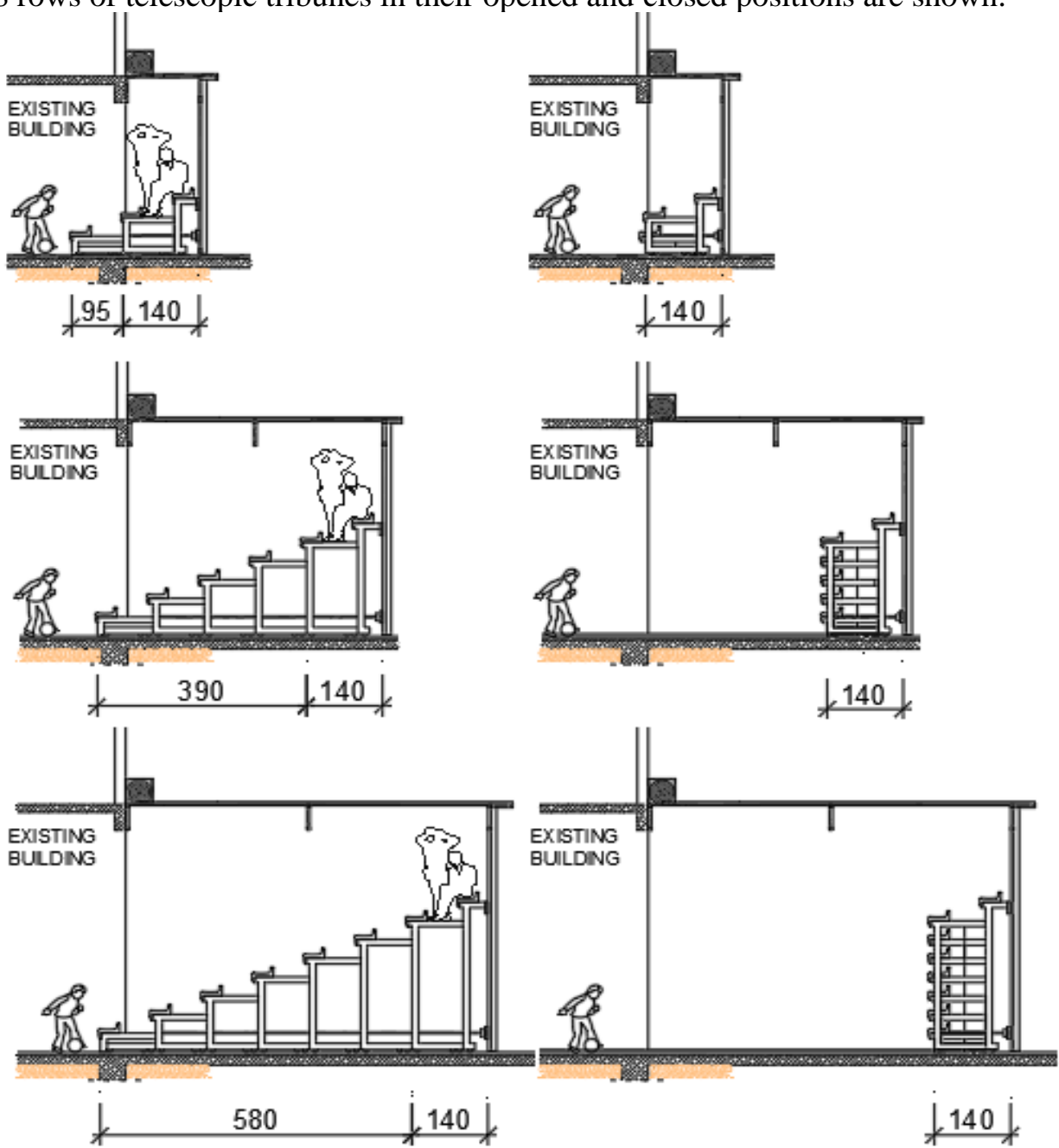

Figure 21. The depth measurements of 3, 6 and 8 rows of telescopic tribunes in their opened and closed positions.

For six different types, the amount of space loss or gain that may occur as a result of the different movements of the building elements has been calculated approximately on the plan diagrams. Exact values can only be calculated from actual dimensions and manufacturing details. Also, in order to see the advantages of the proposed kinetic design, it should be compared with the stable systems. In order to make a comparison, the lost or gained areas have been checked and shown on a chart for folowing types and movements.

- Fixed walls / stable tribunes

- Fixed walls / Closed telescopic tribunes

- Proposed design / Closed walls / Closed telescopic tribunes

- Proposed design / Opened walls / Opened telescopic tribunes

- Proposed design / Opened walls / Closed telescopic tribunes

Negative values in Table 2 show the loss of space and positive values show the gain of space. According to Table 2, in systems with movable walls and telescopic tribunes, as the number of tribune rows increases, gained space increases. 
Table 2. Comparison of fixed and mobile system for different types.

\begin{tabular}{|c|c|c|c|c|c|c|c|}
\hline \multicolumn{3}{|c|}{ Status of Building Elements } & \multirow[t]{2}{*}{\begin{tabular}{|c} 
Fixed walls/ \\
Stable tribunes \\
36 \\
\end{tabular}} & \multirow{2}{*}{\begin{tabular}{|c} 
Fixed walls/ \\
Closed tribunes \\
0 \\
\end{tabular}} & \multirow{2}{*}{$\begin{array}{c}\text { Proposed design / } \\
\text { Closed walls / } \\
\text { Closed tribunes } \\
0\end{array}$} & \multirow{2}{*}{$\begin{array}{c}\text { Proposed design / } \\
\text { Opened walls / } \\
\text { Opened tribunes } \\
36\end{array}$} & \multirow[t]{2}{*}{$\begin{array}{c}\text { Proposed design / } \\
\text { Opened walls / } \\
\text { Closed tribunes } \\
0 \\
\end{array}$} \\
\hline \multirow{6}{*}{ 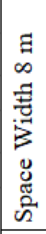 } & \multirow{2}{*}{$\begin{array}{c}\text { Type A } \\
\text { 3 Rows Tribunes }\end{array}$} & Number of Seats & & & & & \\
\hline & & Loss/gain of area $\left(\mathrm{m}^{2}\right)$ & -14 & -8 & -6 & -6 & -2 \\
\hline & \multirow{2}{*}{$\begin{array}{c}\text { Type B } \\
6 \text { Rows Tribunes }\end{array}$} & Number of Seats & 72 & 0 & 0 & 72 & 0 \\
\hline & & Loss/gain of area $\left(\mathrm{m}^{2}\right)$ & -31 & -8 & -2 & -2 & +27 \\
\hline & \multirow{2}{*}{$\begin{array}{c}\text { Type C } \\
\text { 8 Rows Tribunes }\end{array}$} & \begin{tabular}{|l|} 
Number of Seats \\
\end{tabular} & 96 & 0 & 0 & 96 & 0 \\
\hline & & Loss/gain of area $\left(\mathrm{m}^{2}\right)$ & -42 & -8 & -2 & -2 & +42 \\
\hline \multirow{6}{*}{ 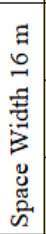 } & \multirow{2}{*}{$\begin{array}{c}\text { Type D } \\
3 \text { Rows Tribunes }\end{array}$} & Number of Seats & 72 & 0 & 0 & 72 & 0 \\
\hline & & Loss/gain of area $\left(\mathrm{m}^{2}\right)$ & -28 & -17 & -13 & -13 & -2 \\
\hline & \multirow{2}{*}{$\begin{array}{c}\text { Type } \mathrm{E} \\
\text { 6 Rows Tribunes }\end{array}$} & Number of Seats & 144 & 0 & 0 & 144 & 0 \\
\hline & & Loss/gain of area $\left(\mathrm{m}^{2}\right)$ & -63 & -17 & -6 & -6 & +54 \\
\hline & \multirow{2}{*}{$\begin{array}{c}\text { Type } \mathrm{F} \\
8 \text { Rows Tribunes }\end{array}$} & Number of Seats & 192 & 0 & 0 & 192 & 0 \\
\hline & & Loss/gain of area $\left(\mathrm{m}^{2}\right)$ & -85 & -17 & -6 & -6 & +85 \\
\hline
\end{tabular}

\section{CONCLUSION AND EVALUATION}

It was seen that researches about kinetic architectural design, the purposes of moveable structures are commonly for control daylight, security, climate and acustic control. The difference of this article is utilization kinetic design for functionality.

In this study, we created new kinetic solutions for structural flexibility, and showed the advantages they provide. Advantages of the proposed design are:

- The system meets the various user needs by opening and closing the telescopic tribunes and folding walls and has the ability to expand the usage area when desired.

- Especially in cold weather, the cost of heating is reduced as space can become smaller.

- The design meets the needs for the required changes easily and practically.

- The design can be implemented during the construction of the building, or it can be added to any existing structure later.

- It can be added to any building from the outside without a need for any change inside.

- Since this system is entirely prefabricated, removable, and foldable, it is easy to carry, assemble, and apply.

- Since it is a self-supporting system, it can not only be installed on the facade of a building but can also be used as independent stands outside when adapted.

- The system can be adapted to smart buildings. The system can be operated automatically according to user needs by sensors and control systems. Also, the system can be operated manually when requested.

- It is a system that has not been implemented before and is suitable for development by designers for special situations.

Points to be considered in this design are:

- The gaps left for the movement of the system must be closed with special detail solutions to provide the needed insulation after the movement is completed.

- Installation and assembly of prefabricated elements requires knowledge and fine craftsmanship.

- The floor on which the system moves should be arranged to be suitable for both indoor and outdoor spaces.

- In order to visually harmonize the movable design added to the existing buildings' facade, the facade study should be done well, e.g. the color of the wall material or the occupancy /void rate. Otherwise, the added new structure may create an irrelevant and ugly image.

- For the feasibility of the design, the properties of the land, parcel status, and zoning regulations should be suitable.

Although the system has advantages, special details are needed that require an interdisciplinary study and expertise in its implementation and also requires trained workmanship. Technological developments, cheaper material alternatives and increased interdisciplinary studies support the kinetic 
architecture practices, and it is thought that the number of such applications will increase day by day. The intensive use of sensors, digital and $3 \mathrm{~d}$ printing technologies are seen as another future application in the kinetic architecture.

\section{REFERENCES}

1. Fox, M. ve Kemp, M., "Interactive Architecture”, Prinston Architectural Press, New York, USA. 2009.

2. Beyazıt, N., "Konut Araçları Açısından Ele Alınan Sistematik Bir Tasarlama Yönteminin Geliştirilmesi”, İstanbul: İstanbul Teknik Üniversitesi Mimarlık Fakültesi, Page 8, 1969.

3. Korkmaz, K., “Kinetik bir mimarlığa doğru”, Ege Mimarlık, Vol. 1, Issue 37, Pages 8-11, 2001.

4. Internet: Türk Dil Kurumu Sözlüğü, “Güncel Türkçe Sözlük”, https://sozluk.gov.tr/, September 27, 2021.

5. Kronenburg, R., "Houses In Motion, The Genesis, History and Development of the Portable Building”, Page 52, Second Edition, Wiley Academy, Great Britain, 2002.

6. De jong, S., "The Companions to the History of Architecture", Edited by David Leatherbarrow and Alexander Eisenschmidt, Volume IV, Twentieth-Century Architecture. Published by John Wiley \& Sons, Inc., Chichester, West Sussex, 2017.

7. Korkmaz, K., “Kinetik Mimarlık Üzerine”, Arredamento Mimarlık, Issue 3, Pages 64-69, 2009.

8. Aisslinger, W., “Studio Aisslinger, Loftcube”. Detail, Vol. 44, Issue 12, Pages 1442-1443, Dec., 2004.

9. Yıldiz, A. E., "Mobile Structures of Santiago Calatrava: Other Ways of Producing Architecture", M.Sc. thesis, Middle East Technical University, Ankara, 2007.

10. Gantes, C. J., “Deployable Structures Analysis and Design”, Page 13, Wit Pres, Southampton, 2001.

11. Internet: Honoring Architecture's Digital Pioneers, https://www.archdaily.com/429862/ honoringarchitecture-s-digital-pioneers_hoberman-jpg, September 27, 2021.

12. Hertel, H., "Structure, Form, Movement", Page 101, Reinhold Publishing Corporation, New York, 1966.

13. Fisher, D., "Rotating Tower Dubai”, CTBUH 8th World Congress, Page 2, Dubai, 2008.

14. MEGEP, “Mekanizma Tekniği-4 Endüstriyel Otomasyon Teknolojileri”, Page 37, T.C. Milli Eğitim Bakanlığı, Ankara, 2007.

15. Internet: Dezeen Awards 2020, Online: https://www.dezeen.com/2009/01/19/sliding-house-by-drmm-2/ September 27, 2021.

16. Altun, T. D. A., “Geleceğin Mimarlığı: Bilimsel-Teknolojik Değişimlerin Mimarlığa Etkileri”, Dokuz Eylül Üniversitesi Mühendislik Fakültesi Fen ve Mühendislik Dergisi, Vol. 9, Issue 1, Pages 83-88, 2007.

17. Bernardi, M., Bley, H. and Schmitt, B. "New approaches for developing mechatronical products in multidisciplinary teamwork", Paper presented The 35th CIRP-International Seminar on Manufacturing Systems, Pages 13-15, 2002.

18. İnternet: https://www.gettyimages.co.uk/photos/bill-gates-house, September 27, 2021.

19. Seçer Karıptaş, F., Güney Karadişoğulları, Ö., “Akıllı ve Sürdürülebilir Binalar”, Çatı ve Cephe, Cilt: 9, Sayı 55, Pages 76-79, 2015.

20. H. Andrä, R. Fink, "Renewing the Reichstag", Structural engineering international, Vol.7, Issue 4, Pages 245-248, 1997. 
21. İnternet: waagner biro, https://wb-sg.com/projects/reichstagdome/, September 27, 2021.

22. Sönmez, B., Çakır, G., "Çevresel, Sosyal ve Ekonomik Bağlamda Akıllı Cephe Sistemlerinin Sürdürülebilir Kalkınmaya Etkileri”, Haliç Üniversitesi Fen Bilimleri Dergisi, İstanbul, Türkiye, Cilt:1, Sayı 1, Sayfa 6398, 2018.

23. Boake, T., M., "Hot climate double facades: Avoiding solar gain”, Facade Tectonics. Vol. 14, Pages 2-24, 2014.

24. Attia S, Bashandy H., "Evaluation of adaptive facades: The case study of AGC headquarter in Belgium". In: Belis J,Louter C, eds. Challenging Glass 5. Conference on Architectural and Structural Applications of Glass. Ghent, Belgium: Ghent University, 2016.

25. Wood, A., Best Tall Buildings: The 2010 CTBUH Reference Guide, New York, NY: Routledge, 2013.

26. İslamoğlu, Ö., Usta, G., "Mimari Tasarımda Esneklik Yaklaşımlarına Kuramsal Bir Bakış”, The Turkish Online Journal of Design, Art and Communication - TOJDAC, Vol. 8, Issue 4, Pages 673-683, 2018.

27. Norberg-Schulz, C., Intention in Architecture, Allen and Unwin Ltd., Universitet for laget, Oslo, Pages 103175, 1966.

28. Ferschin, P., Di Angelo, M., Brunne, G., "Rapid Prototyping for Kinetic Architecture", Conference: 2015 IEEE 7th International Conference on Cybernetics and Intelligent Systems (CIS) and IEEE Conference on Robotics, Automation and Mechatronics (RAM), July, 2015. 